Historia Slavorum Occidentis

2021, nr 4 (31)

ISSN 2084-1213

DOI: $10.15804 / \mathrm{hso} 210414$

Damian Szymczak (Poznań)

ORCID: 0000-0001-6113-6030

\title{
Anatomia galicyjskiego uchodźstwa pierwszowojennego. Recenzja książki Kamila Ruszały Galicyjski Eksodus. Uchodźcy podczas I wojny światowej w monarchii Habsburgów (Kraków 2020, ss. 478)
}

Uchodźstwo spowodowane działaniami wojennymi to dziś jeden z najbardziej palących problemów współczesnego świata. Co więcej, ludzkość wkroczyła, w ujemnym tego słowa znaczeniu, na nowy, bardziej „zaawansowany” poziom traktowania tego fenomenu, czyniąc $\mathrm{z}$ tragedii uchodźców kartę przetargową w politycznych interesach bądź po prostu broń w tzw. konfliktach hybrydowych. Ucieczki przed wojnami, konfliktami, przemocą są oczywiście tak stare jak dzieje ludzkości. Zjawiska te nie omijały i ziem polskich w różnych epokach. Asumpt do badań nad tym zagadnieniem dała przypadająca kilka lat temu setna rocznica wybuchu pierwszej wojny światowej. W jej trakcie problem uchodźstwa wojennego wystąpił ze szczególnym natężeniem w Europie na obszarach objętych działaniami wojennymi. Masowe, niejednokrotnie przymusowe migracje ludności cywilnej w latach Wielkiej Wojny dokonywały się w znajdującym się pod panowaniem Romanowów Królestwie Polskim oraz w należącej do monarchii habsburskiej Galicji. Ten pierwszy temat, tzw. bieżeństwa, podjął zespół lubelskich historyków w osobach Mariusza Korzeniowskiego, Dariusza Tarasiuka i Marka Mądzika ${ }^{1}$. Nad drugim obszarem pochylił się

1 M. Korzeniowski, M. Mądzik, D. Tarasiuk, Tułaczy los. Uchodźcy polscy w imperium rosyjskim w latach pierwszej wojny światowej, Lublin 2007. 
natomiast krakowski historyk Kamil Ruszała. Efektem jego badań jest monografia Galicyjski Eksodus. Uchodźcy podczas I wojny światowej w monarchii Habsburgów.

Autor, przymierzając się do realizacji projektu, wykazał nie tylko ambicję, lecz także odwagę. Przyszło mu bowiem zmierzyć się z niebywale skomplikowanym, obszernym i jednocześnie wielowymiarowym zagadnieniem. Wnikliwe zbadanie problemu galicyjskiego uchodźstwa pierwszowojennego wymagało solidnej kwerendy archiwalnej w licznych krajowych i zagranicznych archiwach, a także umiejętności czytania w kilku językach. Uprzedzając konkluzję recenzji - zadaniu temu Kamil Ruszała niewątpliwie sprostał. Dodać należy, że kwestia galicyjskiego wychodźstwa w okresie pierwszej wojny światowej nie została jak dotychczas całościowo omówiona. Poszczególni badacze do tej pory przedstawili jedynie drobne wycinki uchodźczej epopei Galicjan z okresu 1914-1918². Stąd praca K. Ruszały nosi znamiona dzieła pionierskiego.

Zasadnicze rozważania zostały poprzedzone obszernym rozdziałem wprowadzającym. Autor, zgodnie z zasadami warsztatu naukowego historyka, przedstawił w nim kwestie metodologiczne, stan badań, strukturę pracy, a przede wszystkim gruntownie wyjaśnił terminologię, którą konsekwentnie stosuje w pozostałych częściach opiniowanej monografii. Warto w tym miejscu zauważyć - co czyni też w pracy K. Ruszała - że już w trakcie Wielkiej Wojny stosowanie np. terminu uchodźca na określenie ludzi opuszczających niejednokrotnie pod przymusem rodzinne strony sprawiało trudności interpretacyjne i wywoływało kontrowersje wśród publicystów i polityków.

Strukturze pracy nadano charakter „kombinowany” (tj. chronologiczno-problemowy). Z jednej strony bowiem należało uwzględnić aspekt chronologiczny dziejów galicyjskiego uchodźstwa. $Z$ drugiej zaś problemowy, co jest zabiegiem udanym, harmonijnie i spójne ukazującym dole i niedole wojennych migrantów. Pierwszy rozdział został zatem poświęcony okolicznościom i przebiegowi samego „eksodusu”, ostatni piąty zaś równie trudnemu, jak się okazuje, momentowi powrotu. Rozdziały drugi, trzeci i czwarty mają natomiast ów charakter „kombinowany”. Dotyczą bowiem okresu właściwego wychodźstwa, tj. przymusowego pobytu ludności cywilnej

2 A.K. Banach, Szkolnictwo polskie dla wychodźców z Galicji i Bukowiny, Przegląd Historyczno-Oświatowy XXXVI (1993), nr 1-2; W. Wróbel, Troska biskupa Adama Sapiehy o wysiedlonych i uchodźców w latach 1914-1916, Kraków 1999; S. Wnęk, Rzeszowianie jako uchodźcy wojenni terenie monarchii habsburskiej jesieniq 1914 roku. Liczba, rozmieszczenie i struktura społeczna, [w:] Krajobraz niepodległości. Życie codzienne u progu wolnej Polski, red. J. Hoff, I. Wodzińska, Kolbuszowa 2019, s. 254-278. 
poza Galicją. Autor dokonał w nich jego analizy pod względem: warunków mieszkaniowych, relacji z autochtonami, organizacji pomocy, szeroko rozumianych problemów egzystencjalnych uchodźców itd. Lektura tych części monografii pozwala zauważyć wysokie kompetencje Autora, który wychodząc poza tzw. klasyczną historię, uczynił przedmiotem swoich dociekań zagadnienie tożsamości, mentalności, kwestie psychologiczne czy historię pamięci. Kamil Ruszała zwraca uwagę nawet na niedoceniany fenomen zabobonności jako sposobu myślenia motywującego ludzkie decyzje (s. 46). W narracji świetnie i płynnie przechodzi od syntezujących stwierdzeń do potwierdzających je studiów przypadków i odwrotnie. Poszczególne zagadnienia są punktem wyjścia do ciekawych ogólniejszych rozważań. Te refleksje K. Ruszały dotyczące m.in. ważnego problemu tożsamości mieszkańców imperium Habsburgów, zderzenia, jeśli nie nacjonalizmów, to na pewno „kultur”, nawiązują do szerszej dyskusji, która została podjęta choćby w interesującej książce Pietera Judsona ${ }^{3}$. Warto także zauważyć, że lektura monografii K. Ruszały prowadzi do konstatacji, jak niewiele wiedzieli o sobie mieszkańcy monarchii habsburskiej (owa „wspólnota narodów”), jak stereotypy (utrwalane przez lata choćby przez prasę i powielany tam często obraz zacofanej Galicji i jej mieszkańców ${ }^{4}$ ) dyktowały wyobrażenie o współmieszkańcach różnych narodowości zamieszkujących państwo Franciszka Józefa. Równocześnie Kamil Ruszała znakomicie prezentuje się jako „klasyczny” historyk. Metoda ilościowa, ujęta w liczne tabelki, wykresy, plany, mapki, wyliczenia, skrupulatnie zebrane i przeliczane dane świadczą o benedyktyńskiej wręcz pracy nad archiwaliami. Całość uzupełniona została ciekawym, w wielu wypadkach po raz pierwszy zaprezentowanym materiałem ilustracyjnym. Wreszcie monografię wieńczy udane zakończenie. Dodać należy, że chronologicznie praca wychodzi nawet poza „życie” monarchii habsburskiej, podejmując wątek tych post-Galicjan, którzy jeszcze po 1918 r. pozostali na terytoriach jej państw sukcesyjnych.

Praca, jak już wspomniałem, dostarcza wielu interesujących spostrzeżeń dotyczących natury Austro-Węgier jako państwa. Pewne ułomności i słabości tego organizmu ukazały się w pełnej krasie właśnie w momencie próby, jaką była Wielka Wojna, czego dowodzi opiniowana monografia. I nie chodzi tu o kwestie stricte militarne. Uderza choćby logistyczne nieprzygotowanie do konfliktu, do którego szykowano się przecież od lat. Mam tu na myśli fakt, że władze wojskowe i cywil-

\footnotetext{
3 P.M. Judson, Imperium Habsburgów. Wspólnota narodów, Warszawa 2017.

4 Przykładowo na ten temat. M. Siadkowski, Szlachcicen. Przemiany stereotypu polskiej szlachty w Wiedniu na przełomie XIX i XX wieku, Warszawa 2011.
} 
ne niemal zupełnie lekceważyły problem ewakuacji ludności cywilnej oraz zapewnienia jej ochrony w czasie wojny. Nawet ewakuacja aparatu urzędniczego nie została dopracowana. Protezy odpowiedniego ustawodawstwa przygotowywano już de facto w trakcie działań wojennych. Jeszcze bardziej frapujący był brak zaufania władz centralnych państwa nie tylko do własnych obywateli (fenomen szpiegomanii i oskarżeń o nielojalność mieszkańców Galicji), lecz także do lokalnego samorządu. W takiej atmosferze królować mógł tylko chaos, a jego ofiarą padli w pierwszym rzędzie uchodźcy. Niemniej istotne są pytania: skąd brał się ów brak zaufania? Czy wojskowi myśleli o mieszkańcach państwa jeszcze w kategoriach „poddanych”, a nie obywateli? Przedmiotowo, a nie podmiotowo - a więc de facto post-feudalnie? Czy może owo myślenie odnosiło się jedynie do Galicji? Znawca problemu Michał Baczkowski podkreślał, że „do pełnej identyfikacji Galicjan z wyższych warstw społecznych z wojskiem, poza wyjątkami nigdy nie doszło”. Co więcej, owa „identyfikacja” zaczęła przed pierwszą wojną światową erodować również u warstw niższych, tych najbardziej świadomych narodowo.

Kamil Ruszała problemu uchodźstwa nie ogranicza tylko i wyłącznie do ludności polskiej, choć gdy idzie o osobiste relacje z wojennej odysei, w większości pochodzą one od przedstawicieli naszego narodu. Zwraca tu jednak uwagę na to, że Polacy już w okresie wojny rozumieli wagę dokumentowania losów swojej wygnańczej niedoli. Natomiast trudno znaleźć przejawy takiej świadomości u Ukraińców i Żydów. Marginalnie natomiast dotknięto w monografii los galicyjskich Niemców, liczebnie niewielkiej grupy w ośmiomilionowej społeczności prowincji. W tym względzie wskazałbym na interesujący przyczynek: Galizien und sein Deutschtum. Eine Dokumentation aus Sepps Müllers Nachlaß ergänz durch Beiträge weiterer Autoren, zahlreiche Bilder und Unterlagen des Hilfskomitees der Galiziendeutsche 1952-1953, Bd. I-II, (Stuttgart 2002), w którym w kilku miejscach naświetlono tę kwestię z niemieckiej właśnie strony. Nie zauważyłem również wzmianek o życiu elit na uchodźstwie, przede wszystkim w Wiedniu. Znaczna grupa emerytowanych wysokich urzędników i dygnitarzy, polityków, arystokracji i bogatego ziemiaństwa zbiegła nad Dunaj, choć ich życie tutaj toczyło się zgoła innym torem niż zwykłych galicyjskich wygnańców. Jako postulat na przyszłość można wskazać i inne nisze badawcze, a więc przemoc (także seksualna), rozbite rodziny, problem zdrad, różnego rodzaju patologie występujące na uchodźstwie, zapewne nie tylko w tzw. obozach barakowych. Dodajmy, że w placówkach

5 Jak sądzę, problem wymagałby dodatkowych badań. M. Baczkowski, Pod czarno-żóttymi sztandarami. Galicja i jej mieszkańcy wobec austro-wegierskich struktur militarnych 1868-1914, Kraków 2013, s. 399. 
tych żyły ze sobą na niewielkiej przestrzeni osoby reprezentujące różne stany i klasy społeczne czy poziom wykształcenia, nie wspominając już o poglądach politycznych, co również musiało prowadzić do napięć. Piszący te słowa jest naturalnie świadom, jak niezwykle trudno uchwycić źródłowo wspomniane kwestie, aczkolwiek zapewne będące codziennością znajdujących się na obczyźnie Galicjan. Dodajmy, że swoistej rywalizacji (a co za tym idzie i konfliktów) nie brakowało pomiędzy komitetami niosącymi pomoc uchodźcom, choćby w trakcie zabiegów o środki z kasy państwowej. Niejednokrotnie obok szczerze zaangażowanych w akcję ratunkową działali i różnego rodzaju oszuści, hochsztaplerzy i „kombinatorzy”, próbujący tanim kosztem „ustawić się" w trudnych wojennych czasach. W książce uwagę przykuwają fragmenty poświęcone trudnej sytuacji uchodźców w Zalitawii. Zwłaszcza w kontekście polskich uciekinierów bolesne musiało być zderzenie z potocznym, pozytywnym wyobrażeniem „bratanków” -Węgrów. Pytanie oczywiście, czy ów pozytywny stereotyp rzeczywiście był tak żywy w Galicji, jak to sobie dziś wyobrażamy?

Wypada się zgodzić z Autorem, że tragiczne doświadczenie uchodźstwa przyczyniło się w znaczącym stopniu do osłabienia wiary w państwo Habsburgów. W oczach uciekinierów, jak udowadnia K. Ruszała, zawiodło ono całkowicie. W wypadku Polaków ułatwiło to rozwód z monarchią, która okazała się nie matką, lecz macochą. Dodałbym tylko, że do ostatecznej apostazji przyczynił się nie tylko pokój brzeski z lutego 1918 r., ale także (moim zdaniem) Akt 5 XI 1916 r. Świętowana powszechnie proklamacja odbudowy Królestwa Polskiego musiała budzić w polskich Galicjanach mieszane uczucia, gdyż oznaczała, że pozostaną poza powstającym państwem polskim ze stolicą w Warszawie. Od tego momentu determinantą działań polskich polityków musiało być zjednoczenie z Królestwem Polskim. I coraz mniejszego znaczenia nabierała okoliczność, czy w duecie z monarchią habsburską, czego wyrazem była słynna krakowska rezolucja Koła Sejmowego z 28 V 1917 r. Z monografii nie udało mi się również wyłuskać (może zostało to za mało wyraźnie powiedziane), na jakiej podstawie jednych uciekinierów kwalifikowano do tzw. obozów barakowych, a innych do gmin uchodźczych (s. 167) ? Czy decydowały o tym posiadane środki pieniężne? Szkoda ponadto, że przy podawaniu wielkości wydatków państwowych (jak rozumiem Przedlitawii) na uchodźców nie umieszczono tego w szerszym kontekście budżetowym, tj. jaką sumę procentowo w stosunku do innych pozycji zajmowały kwoty przeznaczone na udzielenie pomocy nie tylko uciekinierom, lecz także ewakuowanym.

Trudno wytknąć autorowi jakiekolwiek niedopatrzenia w bibliografii. Jest ona obszerna, gruntowna i wyczerpująca. Z drobiazgów dorzuciłbym może biografię 
zasłużonego w akcji pomocy dla uchodźców Zygmunta Lasockiego autorstwa Tomasza Kurpierza, (spuścizna po Lasockim znajduje się w krakowskim Archiwum Nauki PAN i PAU w Krakowie). Imponująco przedstawia się również wykaz archiwów, które odwiedził Kamil Ruszała. Jeśli mógłbym cokolwiek dodać, to może znajdującą się w zasobach warszawskiego Archiwum Akt Nowych spuściznę po Juliuszu Twardowskim. Tenże w czasie wojny jako urzędnik, a następnie szef Ministerstwa dla Galicji zasłynął jako opiekun lwowskiej inteligencji i artystów przebywających na wygnaniu w Wiedniu. Ciekawostką byłby na pewno dziennik wspomnianego w pracy księdza Juliana Łukaszkiewicza, a zawierający spostrzeżenia z jego pobytu w Wiedniu od grudnia 1916 do listopada 1918 r. (Archiwum Państwowe w Rzeszowie) czy dziennikarza Piotra Rysiewicza (rękopis Biblioteki Narodowej w Warszawie), również przebywającego w czasie wojny w naddunajskiej stolicy. Z natury rzeczy i tu przewijają się problemy wychodźstwa. Piszący te słowa zdaje sobie oczywiście sprawę, że właściwie niemal każdy pamiętnik czy dziennik galicyjski z okresu pierwszej wojny światowej musi się przynajmniej otrzeć o sprawę ucieczki ludności cywilnej przed działaniami zbrojnymi.

Troszkę niedbałości znajdujemy w indeksie. Niestety, nie znalazły się tam wszystkie osoby, które pojawiają się w tekście, by wskazać choćby wspomnianego w niniejszej recenzji księdza Łukaszkiewicza (s. 310). Usterkę tę dostrzegłem przynajmniej w kilku przypadkach. Z innych potknięć, Kazimierz Morawski nie piastował teki tzw. Ministra dla Galicji (s. 316). Funkcję tę pełnił jego brat Zdzisław. Nie było instytucji marszałka Wydziału Krajowego. Wydziałowi Krajowemu formalnie przewodniczył marszałek krajowy, który miał tam swojego zastępcę, jednak nie tytułowano go „marszałkiem” (s. 295). Zastanawiająco brzmi informacja z listu burmistrza Pilzna w Czechach przytoczona przez K. Ruszałę na s. 98. Dotyczyła ona skandalicznych warunków transportu uchodźców. Treść brzmi, jakby chodziło o włodarza Pilzna, ale galicyjskiego. Trudno uwierzyć, że tego pierwszego w takim stopniu interesowałby stan sanitarny wagonów, w których podróżowali Galicjanie. Na stronie 292 pojawia się data 30 lutego, co jest naturalnie literówką. Podobna w nazwisku Hermana Liebermana (prawidłowo pisane przez jedno, nie jak w tekście podwójne „n”). Dla jasności dodać należy, że tego typu potknięcia mają zupełnie incydentalny charakter.

Praca została napisana bardzo dobrym językiem, dzięki czemu czytelnik szybko „pochłania” kolejne strony, mimo prawdziwego zalewu informacji i spostrzeżeń. Tu jednak trzeba wyrazić autorowi uznanie. Mając tak ogromny zasób źródłowy, nie „zatapia” tematyki w ogromie mniej istotnych detali. Potrafi panować nad materiałem i zachować równowagę między ogółem a szczegółem. 
Podsumowując, recenzowana książka należy na pewno do ważnych pozycji $\mathrm{w}$ dorobku polskiej historiografii dotyczącej tematyki pierwszowojennej. Jest to opracowanie, po które będą musieli sięgnąć wszyscy zajmujący się okresem pierwszej wojny światowej. Autor dzięki ogromnej pracowitości, determinacji i talentowi zdołał przybliżyć w nowatorski sposób niezagospodarowaną dotychczas lukę w badaniach nad Wielką Wojną. Książka przynosi wiele interesujących ustaleń, porządkuje wiedzę na temat różnych aspektów wychodźstwa wojennego i polityki państwa Habsburgów wobec tego problemu. Została oparta na niezwykle solidnym materiale źródłowym. Wreszcie książka, dotykająca przecież zagadnienia uchodźstwa wojennego w określonym miejscu i w odległym o ponad stulecie okresie Wielkiej Wojny, skłania do niezwykle uniwersalnego i niestety aktualnego spostrzeżenia. Jest to fenomen ponadczasowej i ponadregionalnej niechęci do uchodźców. Kamil Ruszała dostrzega uniwersalne mechanizmy ludzkiej psychologii, strategie zachowania wobec „obcych”, nawet jeśli ów obcy jest „swoim obcym” - współobywatelem i poddanym tego samego monarchy. W tym względzie, co już anonsowałem w pierwszych zdaniach niniejszej recenzji, jego dzieło może wpisywać się w szerszą dyskusję nad jakże dziś aktualnym problemem uchodźców, wypędzonych, wygnanych. Można ponadto stwierdzić, że „nowoczesność” Wielkiej Wojny wyraźnie objawiła się nie tylko przez zastosowanie wynalazków technicznych, lecz także w epizodzie wielkich przymusowych migracji, ich społecznych i politycznych konsekwencjach oraz próbach zarządzania tym zjawiskiem.

\section{Bibliografia}

Baczkowski M., Pod czarno-żóttymi sztandarami. Galicja i jej mieszkańcy wobec austro-węgierskich struktur militarnych 1868-1914, Kraków 2013.

Banach A.K., Szkolnictwo polskie dla wychodźców z Galicji i Bukowiny, Przegląd Historyczno-Oświatowy XXXVI (1993), nr 1-2.

Judson P.M., Imperium Habsburgów. Wspólnota narodów, Warszawa 2017.

Korzeniowski M., Mądzik M., Tarasiuk D., Tułaczy los. Uchodźcy polscy w imperium rosyjskim w latach pierwszej wojny światowej, Lublin 2007.

Siadkowski M., Szlachcicen. Przemiany stereotypu polskiej szlachty w Wiedniu na przetomie XIX i XX wieku, Warszawa 2011.

Wnęk S., Rzeszowianie jako uchodźcy wojenni terenie monarchii habsburskiej jesieniq 1914 roku. Liczba, rozmieszczenie i struktura społeczna, [w:] Krajobraz niepodległo- 
ści. Życie codzienne u progu wolnej Polski, red. J. Hoff, I. Wodzińska, Kolbuszowa 2019, s. 254-278.

Wróbel W., Troska biskupa Adama Sapiehy o wysiedlonych i uchodźców w latach 1914-1916, Kraków 1999.

Nadesłany: 9 IX 2021

Zaakceptowany: 16 IX 2021

Dr hab. Damian Szymczak, prof. UAM

Uniwersytet im. Adama Mickiewicza w Poznaniu

Wydział Historii

ul. Uniwersytetu Poznańskiego 7

61-614 Poznań

e-mail: damiansz@amu.edu.pl 